\title{
The dynamics of parallel economies. Measuring the informal sector in Mexico
}

\author{
Jose Brambila Maciasa, ${ }^{\mathrm{a}, *}$, Guido Cazzavillan ${ }^{\mathrm{b}}$ \\ a University of Reading, UK \\ b University "Ca' Foscari” of Venice, Italy
}

\section{A R T I C L E I N F O}

\section{Article history:}

Received 8 July 2009

Accepted 26 July 2009

\section{Keywords:}

Informal sector

Currency demand

VEC

Remittances

\section{Introduction}

Economies in most of the developing world are characterized by huge informal sectors. In a globalized world dominated by immense economic flows, understanding the causes, the size and the effects of these phenomena represents a priority in the economic literature. Although the problem of informality is not new, an agreement on a unique unanimously accepted definition, a comprehensive theoretical model as well as a clear measuring method are still missing. This confirms the difficulty posed by a phenomenon that operates in the shadows of illegality and whose causes and resources vary among countries. From now on, we will refer to informality as all the income generating activities that are unregulated by institutions. ${ }^{1}$ One of the first authors that analysed informality in the developing world was De Soto (1989), who studied the informal sector in Peru, giving insights and evidence on the development and interactions of Peru's underground economy. However, the first rigorous treatment can be tracked back to Loayza (1997), who used an AK endogenous growth model to study informality causes, and the multiple indicators multiple causes method (MIMIC) to measure the size of informality in Latin America. Unfortunately, estimates of the informal sector are done using cross-section analysis that study short periods of time, thus precluding us from capturing its evolution over time and reaction to economic shocks. In this paper, we will focus on measuring the size and evolution of informality in Mexico, in order to contribute to the understanding of the interactions and effects of the underground economy not observable in the previous regional studies.

The Mexican economy, as the rest of Latin America, has always been characterized by a parallel economy. Street vendors and their micro-businesses, known as "vendedores ambulantes", plague huge areas of all the major urban centres in the country. These irregular economic agents form part of the daily reality of the Mexican life. Far from what could be thought, they are well organized and are under the protection of specific groups in charge of negotiating with, or bribing the

\footnotetext{
* Corresponding address: School of Agriculture, Policy and Development, University of Reading, Early Gate, RG6 6AR, Reading, UK. Tel.: +44 0118378 7693; fax: +4401189756467.

E-mail address: J.BrambilaMacias@reading.ac.uk (Brambila Macias J.).

1 See Portes et al. (1989), and Portes and Haller (2005).
} 
authorities. Their presence is a source of discontent and negative externalities to the formal establishment that continuously lobby for their removal. Informality distorts prices and forces wages below its optimum equilibrium, ${ }^{2}$ giving to formal, national or foreign economic agents the perception of an institutional void, that could have long-run consequences for the economy.

As Roubaud (1995) pointed out, economic agents react to economic shocks adopting new survival strategies. In the case of Mexico, and probably the rest of Latin America, these new survival strategies include the establishment of micro-businesses in the shadow of the informal sector. Employment in this sector appears as a natural alternative to cope with sharp decreases in income, high unemployment rates, continuous economic crisis and adverse business regulations.

In this context, measuring the size of the Mexican informal sector becomes relevant, since it certainly affects the macroeconomy and development of the country. Its magnitude and effects on growth (positive or negative relationship) are still open questions in the literature. ${ }^{3}$

The Mexican authorities are aware of this; so, the Mexican National Statistics Institute (INEGI) conducts surveys in an attempt to measure the quantity of agents that work in the informal sector. ${ }^{4}$ The surveys indicate that almost $30 \%$ of the Economic Active Population (EAP) is engaged in the underground economy. Empirical estimates by Schneider (2002) and Vuletin (2008) attribute a size of 33.2\% and 28.2\% of GDP respectively to the informal sector. Unfortunately, these estimates refer to the late 1990s early 2000s, and are usually point estimates, precluding their use to analyse in depth the phenomenon and its possible evolution over time. Therefore, we decided to estimate a specific informal sector time series for the Mexican economy. In order to do so, we used the "classic" currency demand approach, going back in time as much as the data constraints allowed us.

The rest of the paper is structured as follows. In Section 2, we provide a brief description of the currency demand approach. Section 3 briefly summarizes the data and methodology. In Section 4, we present our results for the vector error correction model (VEC). Next, we used the VEC estimates to compute the size of the informal sector in Mexico. The procedure and the results are summarized in Section 5. Furthermore, in Section 6 we use the estimated time series for the informal sector to analyse its relationship with economic growth, and, finally, in Section 7 we offer some final remarks and policy recommendations.

\section{The currency demand approach}

Before jumping into the technicalities of the currency demand approach, we will describe briefly the whole set of techniques available in the literature to measure informality. We can classify them into three categories ${ }^{5}$ :

(1) Direct Methods: these methods refer usually to public or private surveys ${ }^{6}$ and target directly potential informal workers in an attempt to quantify participation in the underground economy.

(2) Indirect Methods: these methods use discrepancies in official records (differences between official and actual labour force, discrepancies between national income and consumption, different monetary methods, etc.) as proxies of the size of the informal sector. ${ }^{7}$

(3) MIMIC or Model Approach: although this approach seems to belong to the indirect methodology, it differs from the previous methods, since it is able to link unobserved variables to observed indicators, using structural equations that model causal relationships among the unobserved variables. ${ }^{8}$

The currency demand approach can be classified among the indirect methods. This approach has been widely used in the past decades to estimate informality mainly in developed countries. ${ }^{9}$

The family of monetary methods dates back to Cagan (1958), Gutmann (1977) and Feige (1979), but it was Tanzi (1983) that made the currency demand approach very popular among economists. The main assumption supporting this type of approach is that transactions in the informal sector use mostly cash, in order to maintain their activities in the shadows, away from any kind of formal record. So, if we could estimate the amount of cash used for informal transactions, we should be able to infer the size of the informal sector in the economy.

The idea behind the currency demand methods used in the literature is well summarized in a recent critical assessment by Ahumada et al. (2006). Following their work, a typical Cagan (1958) type currency demand function can be written as:

$$
C_{0}=A(1+\Theta)^{\alpha} Y_{0}^{\beta} \exp (-\gamma \mathrm{i})
$$

\footnotetext{
2 See IMF (2005) Country Report on Mexico-Selected Issues.

3 Previous empirical studies have found contradictory evidence on the relationship between informality and growth. On the one hand, Helberger and Knepel (1988), Loayza (1997), and Kaufmann and Kaliberda (1996), among others, find a negative relation. On the other hand, Tedds (1998), Giles and Tedds (2002) and more recently Chaudhuri et al. (2006) find a positive impact of informality on growth.

4 The survey started in 2000 and annual averages are available in the Appendix.

5 See Schneider (2002) for a detailed description.

6 In Mexico, these type of surveys are conducted by the National Statistics Institute (INEGI), while surveys covering a wider sample of countries are conducted by the International Labour Organization (ILO).

7 Examples of these methods can be found in Kaufmann and Kaliberda (1996), and Tanzi (1983).

8 The use of the MIMIC approach for estimation of the informal sector was first introduced by Frey and Weck-Hanneman (1984).

9 See Shima (2004) for Norway; Tanzi (1983) for USA; Klovland (1984) for Norway and Sweden; Bovi and Castellucci (2001) for Italy; Bovi and Dell'Anno (2007) for OECD countries.
} 
where $C_{0}$ stands for observed cash and $\Theta$ represents the variable that gives incentives to make hidden transactions. This is the key variable behind all currency models. ${ }^{10}$ Traditionally this incentive variable has been approximated using government consumption normalized by GDP, tax rates (direct taxes, indirect taxes, etc.) or tax revenues to GDP. An increase in $\Theta$ is expected to have a positive impact on currency demand, since agents will have more incentives to go to the informal sector, demanding more currency for their transactions. $Y_{0}$ is the registered GDP. This variable approximates the level of transactions in the economy. Alternative measures are GDP per capita or consumption per capita. Finally, $i$ is the interest rate and $A, \alpha, \beta, \gamma$ represent positive parameters.

Estimating Eq. (1), we obtain $\hat{C}$. Setting the incentive variable $\Theta$ to zero, and leaving the coefficients of the other variables unchanged, we get $\tilde{C}$. The difference between $\hat{C}$ and $\tilde{C}$ allows us to estimate extra currency, i.e. the amount of currency holdings that are tax induced. In other words, the difference measures the amount of illegal money in the economy. Now, assuming that the velocity of money ${ }^{11}$ is the same in both the formal and informal sector, ${ }^{12}$ we can obtain an estimate of the size of the informal economy multiplying illegal money $(\hat{C}-\tilde{C})$ by the velocity of money $(v=Y / C)$.

\section{Methodology and data}

This study uses annual data series that cover a period from 1970 to 2006. The main sources used to collect the data are: the IMF's International Financial Statistics, the World Bank's World Development Indicators, the Mexican Central Bank (online) database and the Mexican National Statistics Institute (INEGI). A more exhaustive description of the variables and their sources is provided in the Appendix.

As pointed out by Guissarri (1987), one of the first decisions to be taken in a currency demand model is how to deflate the currency series. In the classical approach popularized by Tanzi (1983), the standard procedure imposes currency deflation using M2. ${ }^{13}$ However, this assumption was widely criticized. Spiro (1996) claims that the use of M2 is inadequate, since it contains amounts that correspond to long-term wealth accumulation, while currency is used mainly for transaction processes. Refinements went on and, nowadays, economists studying the informal sector use currency and currency per capita in real terms (see Schneider and Enste, 2000, and Öğünç and Yilmaz, 2000). So, we decided to deflate our series using the national GDP deflator and, in order to capture the long-run relationships of the explanatory variables on currency demand, we set up the following model $^{14}$ :

$$
C_{t}=\beta_{0}+\beta_{1} Y_{t}+\beta_{2} T A X_{t}+\beta_{3} R_{t}+\beta_{4} R E M_{t}+v_{t}
$$

where:

- $C$ corresponds to the natural logarithm of currency in circulation outside the banks normalized by the GDP deflator;

- $Y$ is the log of GDP in real terms;

- TAX represents the log of total tax revenues normalized by GDP;

- $R$ refers to the log of the simple average of existing nominal interest rates;

- REM indicates the log of the amount of remittances received normalized by GDP.

- $v$ is the error term.

The above specification captures the long-run relationships between the explanatory variables and the currency demand. Note that in addition to the standard independent variables, we decided to include remittances. With globalization and massive migrations to the developed world, remittances magnitude has surpassed the one of foreign direct investment in many developing countries, prompting a peak of interest on their economic implications and their role in the long-run.

\footnotetext{
10 Some of the critics to this type of approach refer precisely to the use of taxes as the only incentive for informality, claiming that not all underground activities are due to taxes, so the estimates obtained using the currency method are not able to capture the real level of informality.

11 This assumption is quite reasonable in the Mexican context. According to the "Comision Nacional Bancaria y de Valores" (CNBV), credit cards remain largely an untapped market, and in 2005 Mexicans used cash for more than $86 \%$ of their transactions. Furthermore, Mexico underwent the privatization of its banking system during the late 1990s and the entrance of foreign banks during the early 2000s; nevertheless, private saving decreased. See Bulîr and Swiston (2006).

12 This assumption has been criticized and, as Ahumada et al. (2006) claim, even if the velocity is the same, previous works that find $\beta \neq 1$ (i.e. income elasticity different from 1) are incorrect. Therefore, they propose an alternative way of correcting the estimates.

13 Tanzi (1983) estimated the following equation: $\operatorname{Ln}(C / M 2)=a_{0}+a_{1} \operatorname{Ln} T+a_{2} \operatorname{Ln}(W S / N I)+a_{3} \operatorname{LnR}+a_{4} \operatorname{Ln} Y+e$, where $C / M 2$ is the ratio of currency holdings to money, $T$ is a tax variable, WS/NI is the ratio of wages and salaries in national income, $R$ is a time deposit interest rate and $Y$ is the real per capita income.

14 The model can be interpreted as a log-linearization of Eq. (1).
} 
Foreign Direct Investment vs. Remittances

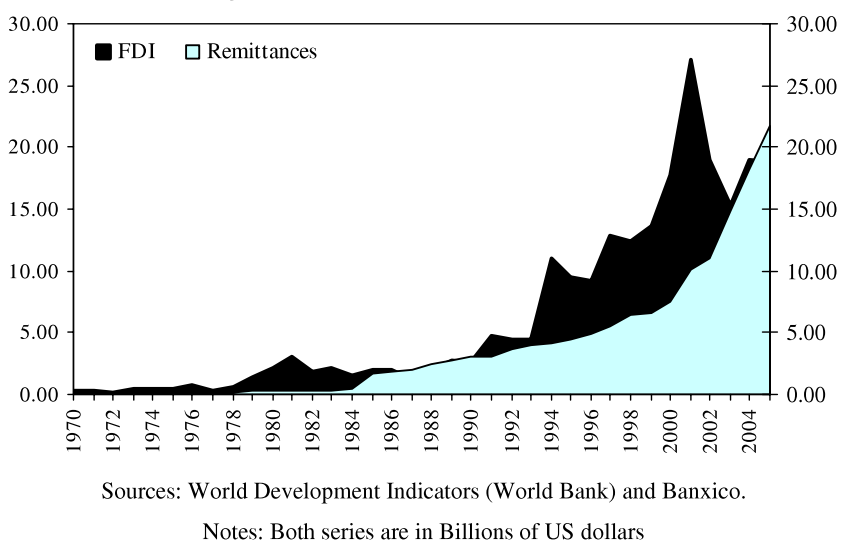

Oil Revenues vs. Remittances as \% of Total Government Revenues

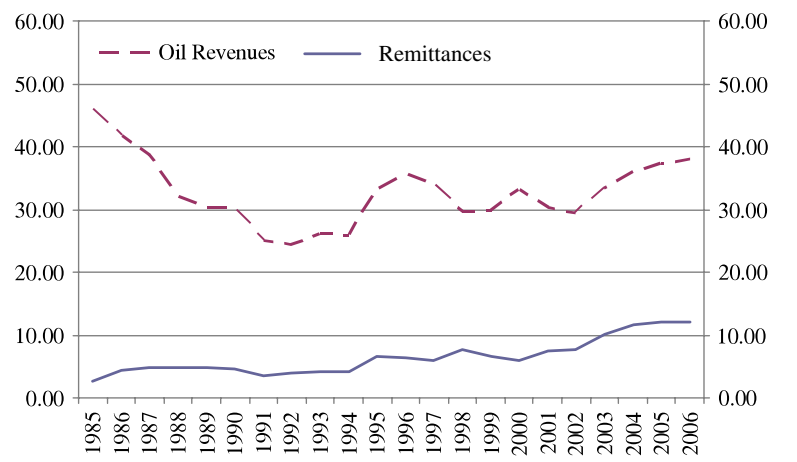

Sources: World Development Indicators (World Bank) and Banxico. Notes: Data is presented as percentages of Total Government Revenues

The text figure plots the evolution of FDI and remittances in Mexico during the past three decades. Although modest during the 1970s, remittances have grown almost exponentially in the past twenty years, gaining weight in the Mexican economic scenario. Indeed, according to the World Bank (2006), remittances in 2003 were the nation's second largest source of external finance after oil revenues ${ }^{15}$ (see text figure), surpassing traditional flows as foreign direct investment (FDI) and tourism revenues. Remittances are expected to have a positive impact on currency demand, especially because they enter the country in the form of money orders or as foreign currency (mainly US dollars) in the pockets of migrant workers. It is important to point out that the series that we are using correspond to "recorded" remittances, which can be seen as a lower bound, since the actual amount is much more above. The World Bank's estimates indicate that the actual amount of remittances could be $50 \%$ higher. ${ }^{16}$ Another reason to include remittances as an explanatory variable has to do directly with informality. Although the former have not been totally associated with money laundry, it is well recognized that migrant workers usually engage in what is known as "smurfing" - separating transfers into smaller packages or different accounts, in order to avoid reporting and fulfilling local requirements such as taxation on larger amounts - giving birth to different kinds of informal flows. ${ }^{17}$ The opaqueness of these channels restraints in deep analysis. However, although the Mexican economy is closely linked to the US dollar, local transactions are made mostly using the national currency. So, migrant workers or their families are forced in one way or another to convert (using formal or informal channels) their dollars into Mexican pesos, thus increasing the demand for currency.

Summarizing, we expect a positive impact on currency demand for GDP, taxes and remittances $\left(\beta_{1}, \beta_{2}, \beta_{4}>0\right)$, since an increase in these variables will put pressure on currency demand. ${ }^{18}$ On the other hand, interest rate increases are expected to have a negative effect, prompting economic agents to get rid of their currency holdings $\left(\beta_{3}<0\right)$.

Before proceeding with the estimation, we tested our series for the presence of unit roots and cointegration ${ }^{19}$ in our main specification. All series turn out to be strongly non-stationary and integrated of order 1 . Trace tests on one hand indicate two cointegrating equations at the $5 \%$ level and one at the $1 \%$ level, while the eigenvalue test indicates one cointegrating equation at the $1 \%$ level. This allows us to conclude that there exists one cointegration relationship. ${ }^{20}$

Given the non-stationarity of our series and the presence of a common stochastic trend, traditional estimation methods are ruled out. So, in order to estimate Eq. (2) and measure the size of the informal sector, we decided to tackle the problem using a vector error correction model (VECM). This type of models present a series of improvements with respect to standard approaches, allowing us to analyse short and long-run effects.

Examples of error correction models to measure informality can be found in works by Bovi (1999), Bovi and Castellucci (2001) and, more recently, in Chiarini and Marzano (2004) with respect to Italy.

The different VECM's estimated in this paper can be defined as follows:

$$
\Delta Y_{t}=\delta+\Gamma_{1} \Delta Y_{t-1}+\Pi Y_{t-1}+\varepsilon_{t}
$$

where $Y$ is a vector formed by the $n$ variables used in our currency demand model (i.e. C, Y, TAX, R and REM ${ }^{21}$ ). $\Pi$ and $\Gamma$ are $5 \times 5$ matrices made up by the system coefficients. If the rank of cointegration $r$ is less than $n$, then $\Pi=\gamma \beta$, where $\gamma$

\footnotetext{
15 According to the Energy Information Administration (EIA), in 2004 Mexico ranked number five as one of the top oil producers of the world. For more details see www.eia.doe.gov/emeu/cabs/.

16 See World Bank (2006), p. xiii and p. 85. and OECD (2007), chapter 6.

17 We refer interested readers to a special report from the World Bank by Hernandez-Coss (2005) dealing with the US-Mexico remittances corridor.

18 Note that the positive impact of taxes on currency demand can be interpreted in Tanzi's spirit as follows: as the level of taxation rises, economic agents will be encouraged to engage tax-evading activities, which are facilitated by the use of currency, due to the intractability of cash; as a consequence, the use of currency rises.

19 The detailed analysis and tests can be found in the Appendix.

20 The existence of only one cointegration vector in our system means that there is a long-run equilibrium relationship between $C, Y, T A X, R$, and $R E M$.

21 The International Bank for Reconstruction and Development/The World Bank (2007), among others, address the issue of potential endogeneity of remittances. So, we include remittances in the set of endogenous variables.
} 
Table 1

Normalized cointegrating coefficients.

\begin{tabular}{|c|c|c|c|c|c|}
\hline Model & & $(1)^{\mathrm{a}}$ & $(2)^{\mathrm{a}}$ & $(3)^{a}$ & $(4)^{b}$ \\
\hline \multirow[t]{2}{*}{ Trace statistic } & $5 \%$ & 2 & 1 & 1 & 3 \\
\hline & $1 \%$ & 1 & 0 & 0 & 1 \\
\hline \multirow[t]{2}{*}{ Max eigenvalue statistic } & $5 \%$ & 1 & 0 & 0 & 1 \\
\hline & $1 \%$ & 0 & 0 & 0 & 0 \\
\hline$C_{t-1}$ & & 1.00 & 1.00 & 1.00 & \\
\hline$C / M 2_{t-1}$ & & & & & 1.00 \\
\hline$Y_{t-1}$ & & $\begin{array}{r}-0.76^{* * *} \\
(0.04)\end{array}$ & $\begin{array}{r}-0.63^{* * *} \\
(0.07)\end{array}$ & $\begin{array}{r}-0.11 \\
(0.18)\end{array}$ & \\
\hline$Y p c_{t-1}$ & & & & & $\begin{array}{l}0.38 \\
(2.20)\end{array}$ \\
\hline$T A X_{t-1}$ & & $\begin{array}{r}-0.49^{* * *} \\
(0.13)\end{array}$ & $\begin{array}{r}-0.44^{*} \\
(0.28)\end{array}$ & & $\begin{array}{c}-12.61^{* * *} \\
(3.78)\end{array}$ \\
\hline$R_{t-1}$ & & $\begin{array}{l}0.09^{* * *} \\
(0.02)\end{array}$ & $\begin{array}{l}0.18^{* * *} \\
(0.03)\end{array}$ & $\begin{array}{l}0.22^{* * *} \\
(0.07)\end{array}$ & $\begin{array}{r}-0.34 \\
(0.40)\end{array}$ \\
\hline$R E M_{t-1}$ & & $\begin{array}{r}-0.12^{* * *} \\
(0.03)\end{array}$ & & & \\
\hline$G O V_{t-1}$ & & & & $\begin{array}{r}-0.03 \\
(0.57)\end{array}$ & \\
\hline Cons & & $\begin{array}{r}-2.75^{* * *} \\
(1.10)\end{array}$ & $\begin{array}{r}-6.97^{* * *} \\
(2.15)\end{array}$ & $\begin{array}{c}-23.39^{* * * *} \\
(4.26)\end{array}$ & $\begin{array}{l}23.87 \\
(23.44)\end{array}$ \\
\hline Log likelihood & & 191.85 & 180.73 & 189.64 & 136.17 \\
\hline $\mathrm{X}^{2}$ & & 673.99 & 141.17 & 21.42 & 11.19 \\
\hline
\end{tabular}

All variables are in natural logs. In addition to the previously described variables in Section 3, we have:

-C/M2: The ratio between currency outside the banks and M2 (broad money);

-Gov: The ratio between government consumption and GDP;

-Ypc: GDP per capita.

Note: All series used in the models are I (1). The complete details of the analysis as well as the matrix of adjustment coefficients can be found in the Appendix. The number of lags in the models were determined using Akaike's information criterion (AIC), Schwarz's Bayesian information criterion (SBIC) and the Hannan and Quinn information criterion (HQIC).

All models we estimated assume one cointegrating equation. Standard errors are in parentheses.

a Model was estimated using two lags.

b Model was estimated using four lags.

$p<0.10$.

$p<0.05$.

$p<0.01$

represents the adjustment coefficients and $\beta$ the cointegrating vectors. Finally, $\varepsilon$ corresponds to our system residuals and $\delta$ is a constant term which can be separated in two parts - a trend term and the intercept - in the cointegrating relation.

\section{Results and their robustness}

In order to test the robustness of our model, we also estimate Eq. (2) without remittances, in addition, following Guissarri's (1987) specification we estimate the model using government consumption normalized by GDP instead of tax burden and finally we use an approximation of the classical Tanzi (1983) model. The long-run cointegrating coefficients are reported in Table 1.

As expected, in model (1), which corresponds to Eq. (2), the coefficients for output, tax burden and remittances have a positive long-run effect, while interest rates take the pressure off currency demand. All coefficients are strongly significant and assign relevant weight to GDP with a coefficient of 0.76 and taxes with 0.49 , while leaving a moderate but not negligible effect to remittances with a coefficient of 0.12 .

The performance of Model (2) is weaker compared to Model (1) and the TAX variable is barely significant; moreover it still retains significance among all its coefficients. On the other hand, Models (3) and (4) fail to maintain significance in all their variables except for taxes and interest rates.

In Model (4) we are forced to approximate Tanzi's original specification using only income per capita, taxes and interest rates in order to explain variations in the currency ratio $(C / M 2)$. This is mainly due to data constraints. Hence, we are not able to include the ratio of wages and salaries, as in the original specification. Nevertheless, the model can be used to measure the explanatory power of this type of specification for the Mexican context, and as we can see from Table 1, this type of modelling has very little explanatory power with respect to the currency ratio in the economy. Furthermore, the interest rates present a negative sign in the cointegrating coefficient $(-0.34)$, which can be interpreted as having a positive effect on currency holdings, which is in contradiction with the economic theory. 


\section{The size of the informal sector}

After estimating the vector error correction model (VECM $)^{22}$ and obtaining the coefficients for the long-run relationship of Eq. (2) reported as Model (1) in Table 1, we proceed to estimate the size of the informal economy.

In order to obtain an estimate of the size of the informal sector, first, we compute $\hat{C}$ using all the coefficients in Eq. (4). Then, we set the tax variable equal to zero and re-estimate the equation keeping all the other coefficients unchanged to obtain $\tilde{C}$.

$$
C=2.75+0.76 Y+0.49 T A X-0.09 R+0.12 R e m .
$$

The difference between these two variables $-\hat{C}$ and $\tilde{C}$ - give us the amount of extra currency in the economy. Following Tanzi (1983), we assume equal velocity in both the formal and informal sector, and estimate it as follows:

$$
\frac{Y}{M 1-E C}=v \text {. }
$$

Eq. (5) yields the velocity of money in the Mexican economy. $Y$ is the GDP, M1 corresponds to total currency and deposits in circulation, and $E C$ stands for extra currency or illegal money.

The difference between $M 1$ and $E C$ can be interpreted as the amount of legal money used in the economy. Once we estimate the velocity from Eq. (5), the size of the informal sector can be obtained multiplying $E C$ by the velocity of money:

$$
E C * v=Y_{\text {informal }}
$$

Using Eq. (6), we can infer the size of the informal sector in formal GDP terms. From Table 1 we can also observe that our coefficient for $Y$ is different from 1. So, in the Ahumada et al. (2006) spirit, we proceed to correct our estimates using their suggested method $^{23}$ :

$$
\frac{Y_{\text {informal }}}{Y_{\text {formal }}}=\left(\frac{C_{\text {informal }}}{C_{\text {formal }}}\right)^{\frac{1}{\beta}}=\left(\frac{\hat{Y}_{\text {informal }}}{\hat{Y}_{\text {formal }}}\right)^{\frac{1}{\beta}}
$$

where $Y$ and $C$ are the GDP and money respectively, while $\beta$ is the income elasticity. The correction basically deflates the "wrong" ratio $\left(\hat{Y}_{\text {informal }} / \hat{Y}_{\text {formal }}\right)$ that we obtained using inappropriately the assumption $\beta=1$. Eq. (7) corrects our estimates when $\beta \neq 1$.

Our original and corrected results normalized by the formal GDP are summarized below (see text figure).

Mexican Informal Economy as percentage of real GDP

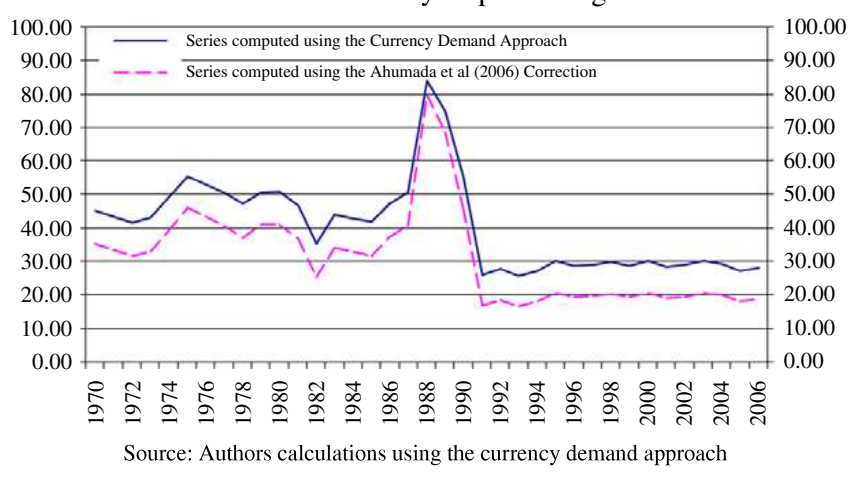

As we can see, informality in the 1990s and early 2000s stabilizes around 20\%-30\% of GDP, which is in line with the previous studies. ${ }^{24}$ The rest of the series, unfortunately, cannot be compared; so, inference should be taken with caution. Informality fluctuated between $50 \%$ and $60 \%$ of GDP during the 1970s and presents a huge jump in the 1980s, reaching almost $85 \%$ of GDP in 1988. Although at first sight this magnitude could seem out of proportion, we should clarify that this period was characterized by great economic and political turmoil in Mexico and the rest of Latin America. Moreover, deep crises and hyperinflation affected the south of the continent, and Mexico registered inflation rates above $100 \%$ (see Fig. 2).

So, in this period, inflation and macroeconomic instability clearly played a major role on currency demand. However, to which extent inflation or informality can explain this peak is difficult to assess. Inflation rates above $100 \%$ occurred in 1983 , 1987 and 1988, while hyper-informality is registered in 1988 and 1989.

Fig. 1 plots both formal and informal series in real terms. If we compare both series, the presence of a parallel economy in Mexico can be appreciated. This underground economy grew continuously during the early 1970s and the late 1980s, accounting on average for almost two thirds of GDP. Informality then fell abruptly in the early 1990s and remained stable around one third of GDP until our days.

\footnotetext{
22 The long-run relationship between our variables was derived normalizing $C$.

23 Ahumada et al. (2006) show that it is wrong to assume the same velocity of money when the hypothesis $\beta=1$ is rejected by the econometric estimation of the currency demand model. This is our case, since our model gives us a coefficient $\beta=0.76$.

24 See, for example, Vuletin (2008), Schneider (2002) and Loayza (1997).
} 


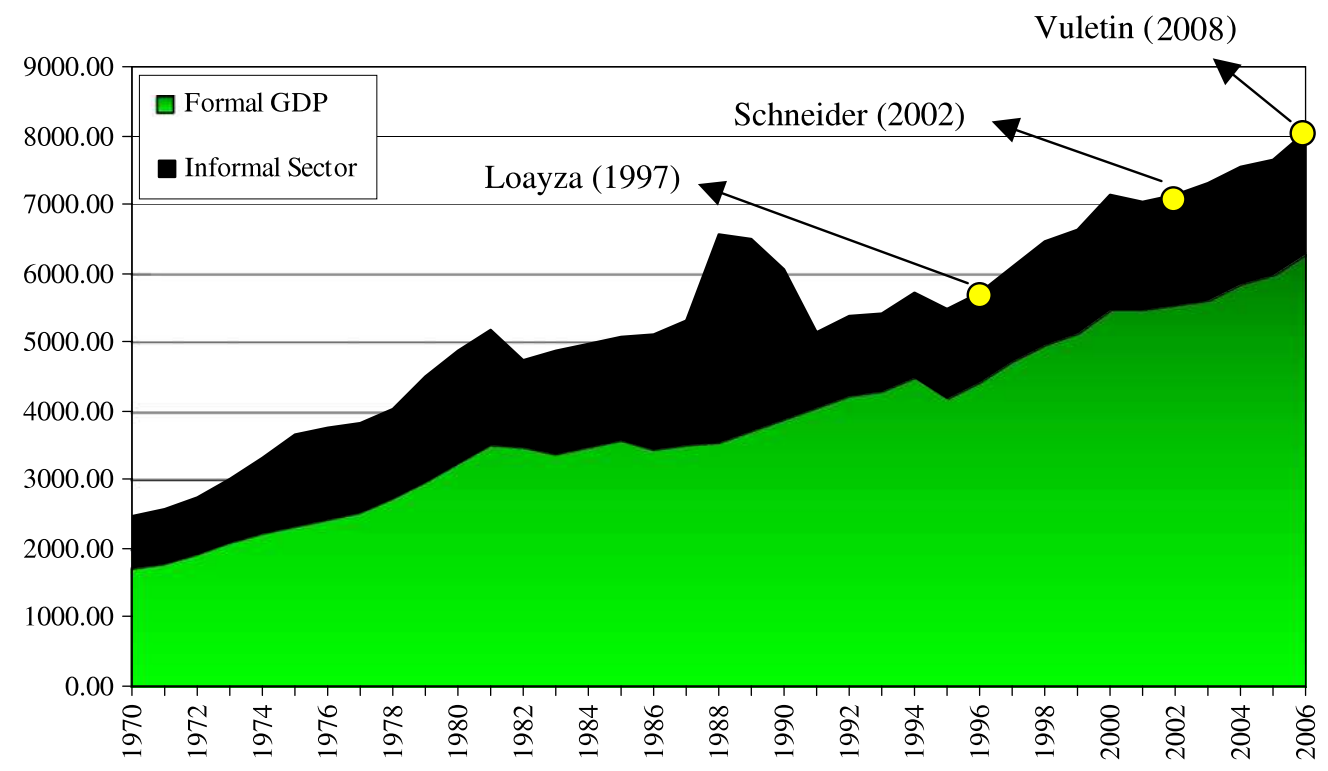

Sources: International Financial Statistics (IMF) and authors calculations using the currency demand approach.

Note: Both formal and informal GDP are in real terms $(2000=100)$, and the vertical axis corresponds to billions of Mexican pesos.

Fig. 1. Mexican informal sector.

Inflation, Unemployment and Remittances

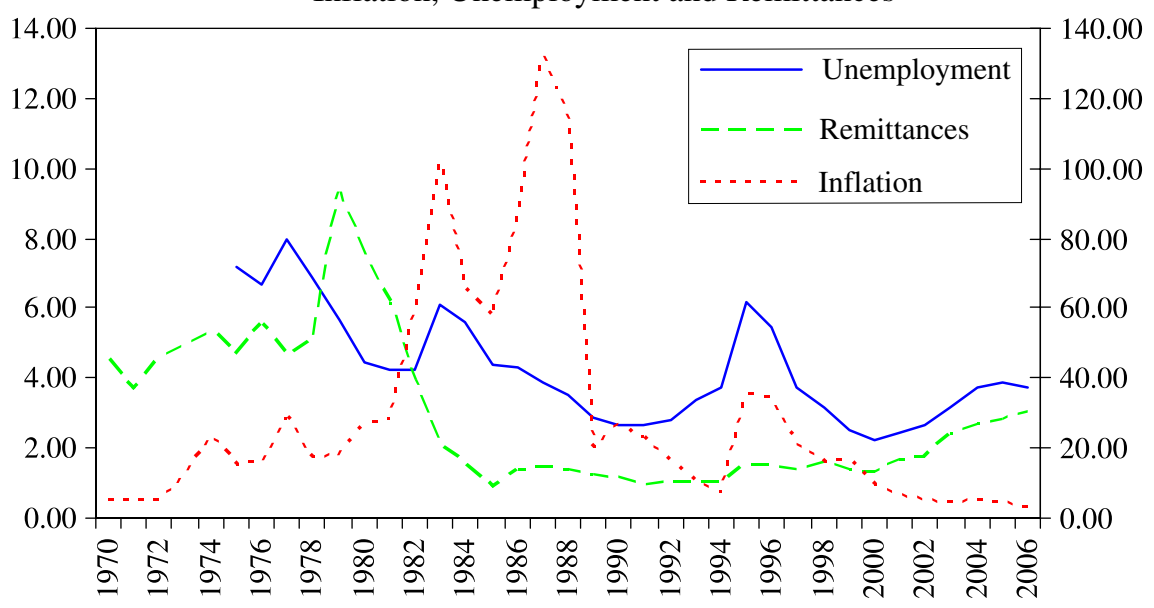

Sources: INEGI, International Financial Statistics (IMF), World Development Indicators (World Bank), Mexican Central Bank (Banxico), INEGI

Note: Right axis corresponds to inflation, both axis in percentage. Unemployment corresponds to the percentage of Economic Active Population, while remittances are in percentage of GDP in national currency.

Fig. 2. Inflation, unemployment and remittances in Mexico (1970-2006).

\section{Informal sector and economic growth}

As we explain in the previous sections of the paper, one of the aims of this study is to estimate a series for the informal sector, in order to use it to establish its long-run relationship with economic growth. To do so, once we have our informal economy series we have decided to apply the general to specific approach. ${ }^{25}$ This methodology starts by setting a large general model that encompasses many explanatory variables (the idea behind this is that the model will lose more explanatory power if relevant variables are omitted rather than if irrelevant variables are included) and slowly start eliminating variables with not significant coefficients until we reach a simpler, but more robust model.

For this part of the study we use annual data starting in 1970 and going all the way until 2006. The sources are again the IMF's International Financial Statistics, the World Bank's World Development Indicators and the Mexican Central Bank (online) database.

We start from an over-parameterized model and slowly pin down variables until we are left with the most significant model. Eq. (8) describes the general economic growth model. In addition to the traditional variables we include the so called

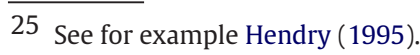


Table 2

Growth regressions (ARDL Models).

\begin{tabular}{|c|c|c|c|c|c|c|c|}
\hline & (1) & (2) & (3) & (4) & (5) & (6) & (7) \\
\hline$Y_{t-1}$ & $\begin{array}{r}-0.950 \\
(0.136)\end{array}$ & $\begin{array}{r}-0.167 \\
(0.126)\end{array}$ & $\begin{array}{r}-0.206^{*} \\
(0.112)\end{array}$ & $\begin{array}{c}-0.243^{* * *} \\
(0.075)\end{array}$ & $\begin{array}{c}-0.260^{* * * *} \\
(0.064)\end{array}$ & $\begin{array}{c}-0.260^{* * *} \\
(0.062)\end{array}$ & $\begin{array}{r}-0.242^{* * *} \\
(0.071)\end{array}$ \\
\hline$\Delta P E_{t}$. & $\begin{array}{r}-0.008 \\
(0.020)\end{array}$ & $\begin{array}{r}-0.007 \\
(0.027)\end{array}$ & $\begin{array}{l}0.001 \\
(0.019)\end{array}$ & $\begin{array}{c}-0.001 \\
(0.022)\end{array}$ & $\begin{array}{l}0.002 \\
(0.018)\end{array}$ & & \\
\hline$P E_{t-1}$ & $\begin{array}{l}0.002 \\
(0.030)\end{array}$ & $\begin{array}{l}0.023 \\
(0.023)\end{array}$ & $\begin{array}{l}0.031^{*} \\
(0.018)\end{array}$ & $\begin{array}{l}0.027 \\
(0.021)\end{array}$ & $\begin{array}{l}0.029^{*} \\
(0.017)\end{array}$ & $\begin{array}{l}0.029^{* *} \\
(0.014)\end{array}$ & $\begin{array}{l}0.027^{*} \\
(0.016)\end{array}$ \\
\hline$\triangle T R A D E_{t}$ & $\begin{array}{r}-0.030 \\
(0.106)\end{array}$ & $\begin{array}{r}-0.055 \\
(0.103)\end{array}$ & $\begin{array}{r}-0.099 \\
(0.087)\end{array}$ & $\begin{array}{r}-0.109 \\
(0.089)\end{array}$ & $\begin{array}{r}-0.128 \\
(0.078)\end{array}$ & $\begin{array}{r}-0.128^{*} \\
(0.075)\end{array}$ & $\begin{array}{r}-0.109 \\
(0.081)\end{array}$ \\
\hline$T R A D E_{t-1}$ & $\begin{array}{l}0.177^{* * *} \\
(0.061)\end{array}$ & $\begin{array}{l}0.082^{*} \\
(0.049)\end{array}$ & $\begin{array}{l}0.076^{*} \\
(0.047)\end{array}$ & $\begin{array}{l}0.043^{* * *} \\
(0.016)\end{array}$ & $\begin{array}{l}0.051^{* * *} \\
(0.014)\end{array}$ & $\begin{array}{l}0.050^{* * *} \\
(0.014)\end{array}$ & $\begin{array}{l}0.044^{* *} \\
(0.016)\end{array}$ \\
\hline$\Delta G O V_{t}$ & $\begin{array}{l}0.112 \\
(0.158)\end{array}$ & $\begin{array}{l}0.138 \\
(0.137)\end{array}$ & $\begin{array}{l}0.170^{*} \\
(0.104)\end{array}$ & $\begin{array}{l}0.115 \\
(0.119)\end{array}$ & $\begin{array}{l}0.148 \\
(0.092)\end{array}$ & $\begin{array}{l}0.146^{*} \\
(0.084)\end{array}$ & $\begin{array}{l}0.117 \\
(0.110)\end{array}$ \\
\hline$G O V_{t-1}$ & $\begin{array}{l}0.123^{*} \\
(0.066)\end{array}$ & $\begin{array}{l}0.142^{* *} \\
(0.068)\end{array}$ & $\begin{array}{l}0.158^{* * *} \\
(0.060)\end{array}$ & $\begin{array}{l}0.153^{* *} \\
(0.065)\end{array}$ & $\begin{array}{l}0.168^{* * *} \\
(0.051)\end{array}$ & $\begin{array}{l}0.168^{* * *} \\
(0.050)\end{array}$ & $\begin{array}{l}0.152^{* *} \\
(0.064)\end{array}$ \\
\hline$\Delta$ Infla $_{t}$ & $\begin{array}{r}-0.007 \\
(0.011)\end{array}$ & $\begin{array}{r}-0.012 \\
(0.013)\end{array}$ & & $\begin{array}{r}-0.008 \\
(0.012)\end{array}$ & & & $\begin{array}{r}-0.008 \\
(0.011)\end{array}$ \\
\hline Infla $_{t-1}$ & $\begin{array}{r}-0.004 \\
(0.010)\end{array}$ & $\begin{array}{r}-0.002 \\
(0.012)\end{array}$ & & $\begin{array}{r}-0.003 \\
(0.006)\end{array}$ & & & $\begin{array}{r}-0.003 \\
(0.006)\end{array}$ \\
\hline$\Delta P_{0} p_{t}$ & $\begin{array}{l}3.474 \\
(8.347)\end{array}$ & $\begin{array}{l}0.122 \\
(9.203)\end{array}$ & $\begin{array}{r}-0.639 \\
(4.988)\end{array}$ & & & & \\
\hline Pop $_{t-1}$. & $\begin{array}{r}-0.154 \\
(0.240)\end{array}$ & $\begin{array}{r}-0.124 \\
(0.233)\end{array}$ & $\begin{array}{r}-0.100 \\
(0.156)\end{array}$ & & & & \\
\hline$\Delta F D I_{t}$. & $\begin{array}{r}-0.015 \\
(0.022)\end{array}$ & & & & & & \\
\hline$F D I_{t-1}$ & $\begin{array}{r}-0.051 \\
(0.030)\end{array}$ & & & & & & \\
\hline Cons & 4.110 & 3.937 & 3.840 & $2.330^{* * *}$ & $2.484^{* * *}$ & $2.493^{* * *}$ & $2.322^{* * *}$ \\
\hline$R^{2}$ & 0.602 & 0.535 & 0.522 & 0.521 & .514 & .514 & .521 \\
\hline RMSE & 0.026 & 0.027 & 0.027 & 0.027 & 0.026 & 0.025 & 0.026 \\
\hline
\end{tabular}

The regressions were estimated using annual data starting in 1970 until 2006. Robust Standard errors in parentheses.

Indicates significance at the $1 \%$ level.

** Indicates significance at the 5\% level.

"Indicates significance at the $10 \%$ level.

Parallel Economy (the informal sector).

$$
\begin{aligned}
\Delta Y_{t}= & a_{1} \Delta \text { Trade }_{t}+a_{2} \Delta \text { Gov }_{t}+a_{3} \Delta \text { Infla }_{t}+a_{4} \Delta \text { Pop }_{t}+a_{5} \Delta \text { PE }_{t}+a_{6} \Delta F I_{t} \\
& +\left(b_{7}-1\right)\left[\begin{array}{l}
Y_{t-1}+\beta_{0}+\beta_{1} \text { Trade }_{t-1}+\beta_{2} \text { Gov }_{t-1}+\beta_{3} \text { Infla }_{t-1}+ \\
\beta_{4} \text { Pop }_{t-1}+\beta_{5} \text { PE }_{t-1}+\beta_{6} \text { FDI I }_{t-1}
\end{array}\right]+v_{t}
\end{aligned}
$$

where:

- $Y$ is real GDP per capita;

- Trade corresponds to (Exp + Imp)/GDP;

- Gov is Government consumption as percentage of GDP;

- Pop indicates demographic developments;

- $P E$ is the parallel economy;

- FDI corresponds to foreign direct investment as percentage of GDP.

From Eq. (8) we are interested in obtaining a simpler model specification from which we can infer the long-run relationship between economic growth and parallel economies.

The results from the various specifications are presented in Table 2. As expected, the initial model, specification (1), although presenting the highest $R^{2}$, includes only two statistically significant variables, TRADE and Gov. So, we start eliminating variables whose coefficients are not significant and that we believe are not relevant for the long-run relationship between growth and informality. Therefore, in specification (3), we eliminate FDI and inflation, that we believe will have more impact in the short-run, indeed, we start getting significance for the Parallel economy variable $\left(P E_{t-1}\right)$, the long-run coefficient 0.031 becomes significant at the $10 \%$ level.

It is important to point out that trade and government consumption remain significant throughout all the models, highlighting their relevance for the Mexican economy. Going on, we arrive at specification (6), where all variables are significant and the parallel economy turns out to have a positive effect on economic growth.

So, using specification (6) we can derive the long-run relationship between the remaining variables and the Mexican economic growth. The long-run model is presented below as Eq. (9).

$$
Y=29.59+0.11 P E+0.19 T R A D E+0.64 G O V .
$$

The former equation shows us the weights of each variable in the long-run and their effects on the Mexican economic growth. We can see that Government consumption represents the biggest driving force of the Mexican economy, being almost 3 times higher than international trade. 


\section{Concluding remarks}

The existence of a parallel economy in Mexico and other Latin American economies is well documented and accepted by the economic literature. It is the size and composition of this sector as well as the measuring methodology that are open to debate. In this paper, we used the currency demand approach to obtain a measure of informality in Mexico from the early 1970s until 2006.

Our results provide an example of the evolution of informality in a developing country. First, the underground economy in Mexico grows constantly during the 1970s until it reaches its maximum in the late 1980s. Then, it decreases sharply and stabilizes around 30\% of GDP. This is not entirely good news. In a country with nearly 100 million inhabitants and 840 billion US dollars of GDP, this amount of informality represents a huge weight on the formal establishment, creating negative externalities, anchoring the nation and precluding it from reaching its real economic potential.

Furthermore, the stagnation of informality that characterized the past decade reflects the failure or lack of public policies targeting the informal sector, which consequently has left a large proportion of economic agents at the margins of the legal framework. Government lack of interest in this area will certainly have a deep impact and a huge cost on output in the long-run.

So, it is imperative to elaborate long-term strategies, in order to help to channel informal agents and their economic flows - i.e. remittances - back to formality. The Mexican government should create the conditions in order to allow informal remittances and income to be converted into productive investment. Successful policies will alleviate pressure on public finances and formal establishments in the short-run, allowing the re-direction of new resources needed to finance growth. On the other hand, in the long-run, the entry of informal agents into the legal framework will add fair competitiveness to the markets rising salaries and production quality.

Finally, Mexican policy makers should focus on the development of a slimmer regulation framework (i.e. fewer bureaucratic procedures, quick times and low costs, but above all less corrupt system), attractive enough to incentive effectively informal agents to come back to the formal economy.

\section{Acknowledgements}

The authors are grateful to Isabella Massa, Davide Bancolini, Maurizio Bovi, Stefano Magrini, Mario Padula, as well as colleagues and participants at the WISE seminars for useful discussions and comments. We are solely responsible for all errors and omissions.

\section{Appendix}

See Tables A.1-A.5.

\section{Table A.1}

Data.

\begin{tabular}{ll}
\hline Variable & Description \\
\hline$C$ & $\begin{array}{l}\text { Natural logarithm of currency over GDP deflator. } \\
\text { 1970-2006 in national currency }\end{array}$ \\
$Y$ & $\begin{array}{l}\text { Natural logarithm of real GDP 1970-2006 in national } \\
\text { currency } \\
\text { Natural Logarithm of 1 + total of tax revenues over GDP } \\
\text { 1970-2006 }\end{array}$ \\
TAX &
\end{tabular}

Sources

International Financial Statistics, (IMF), the series is also available entirely or partially at the Mexican Central Bank Web page (www.banxico.com)

International Financial Statistics, (IMF), the series are also available at INEGI and Banxico's web page.

This series is partially available online, data before the late 1980s are available only on paper records. The series used in this paper comes mainly from the Mexican Central Bank online database (www.banxico.com) Alternative Sources are: The Mexican Secretariat for Public Finance (SHCP), The National Statistics Institute (INEGI), and the Mexican Senate Economic Affairs Center.

$R \quad$ Natural logarithm of the average of time deposit interest This series was calculated using the CPP (costo porcentual promedio) that corresponds to the simple average of nominal interest rates. The registry of this type of index started in 1975, so the series was extended back to 1970. Sources: Mexican Central Bank, alternative source: Diario Oficial de la Nacion World Development Indicators (World Bank) and Banxico. The series was used in national currency

International Financial Statistics(IMF) and Banxico International Financial Statistics (IMF)

World Economic Outlook (IMF) and INEGI. Note: the first estimations were computed by INEGI using as sample only 3 major cities. Nowadays estimates are done in a much wider sample.

Foreign direct $\quad$ Net inflows (BoP current US dollars) 1970-2005 World Development Indicators (World Bank) 
Table A.2

Unit root tests.

\begin{tabular}{|c|c|c|c|c|c|c|}
\hline Test & Variables & C & Y & TAX & $R$ & REM \\
\hline Augmented Dickey-Fuller ${ }^{\mathrm{a}}$ & $\begin{array}{l}\text { Level } \\
\text { First difference }\end{array}$ & $\begin{array}{l}-1.19 \\
-6.68^{* * *}\end{array}$ & $\begin{array}{l}-2.35 \\
-4.12^{* * *}\end{array}$ & $\begin{array}{l}-3.34^{* *} \\
-4.79^{* * *}\end{array}$ & $\begin{array}{l}-0.84 \\
-4.78^{* * *}\end{array}$ & $\begin{array}{l}-1.72 \\
-4.86^{* * *}\end{array}$ \\
\hline Phillips-Perron ${ }^{\mathrm{a}}$ & $\begin{array}{l}\text { Level } \\
\text { First difference }\end{array}$ & $\begin{array}{l}-1.04 \\
-6.72^{* * *}\end{array}$ & $\begin{array}{l}-2.35 \\
-4.12^{* * *}\end{array}$ & $\begin{array}{l}-2.65^{*} \\
-4.77^{* * *}\end{array}$ & $\begin{array}{l}-1.15 \\
-4.77^{* * *}\end{array}$ & $\begin{array}{l}-1.52 \\
-4.91^{* * *}\end{array}$ \\
\hline Augmented Dickey-Fuller ${ }^{\mathrm{b}}$ & $\begin{array}{l}\text { Level } \\
\text { First difference }\end{array}$ & $\begin{array}{l}-2.12 \\
-6.57^{* * *}\end{array}$ & $\begin{array}{l}-3.06 \\
-4.35^{* * *}\end{array}$ & $\begin{array}{l}-2.47 \\
-4.73^{* * *}\end{array}$ & $\begin{array}{l}-1.04 \\
-5.08^{* * *}\end{array}$ & $\begin{array}{l}-0.77 \\
-3.58^{* *}\end{array}$ \\
\hline Phillips-Perron ${ }^{\mathrm{b}}$ & $\begin{array}{l}\text { Level } \\
\text { First difference }\end{array}$ & $\begin{array}{l}-2.14 \\
-6.61^{* * *}\end{array}$ & $\begin{array}{l}-2.45 \\
-4.36^{* * *}\end{array}$ & $\begin{array}{l}-2.63 \\
-4.69^{* * *}\end{array}$ & $\begin{array}{l}-1.13 \\
-5.08^{* * *}\end{array}$ & $\begin{array}{l}-1.11 \\
-4.92^{* * *}\end{array}$ \\
\hline Augmented Dickey-Fuller ${ }^{c}$ & $\begin{array}{l}\text { Level } \\
\text { First difference }\end{array}$ & $\begin{array}{c}1.87 \\
-6.09^{* * * *}\end{array}$ & $\begin{aligned} & 6.24 \\
- & 2.54^{* * *}\end{aligned}$ & $\begin{array}{c}0.49 \\
-4.81^{* * * *}\end{array}$ & $\begin{array}{l}-0.52 \\
-4.83^{\text {**** }}\end{array}$ & $\begin{array}{l}-1.04 \\
-4.93^{* * *}\end{array}$ \\
\hline Phillips-Perron $^{c}$ & $\begin{array}{l}\text { Level } \\
\text { First difference }\end{array}$ & $\begin{array}{l}2.19 \\
-6.09^{* * *}\end{array}$ & $\begin{aligned} & 5.11 \\
- & 2.40^{* * *}\end{aligned}$ & $\begin{array}{l}-0.44 \\
-4.80^{* * *}\end{array}$ & $\begin{array}{l}-0.54 \\
-4.83^{* * *}\end{array}$ & $\begin{array}{l}-1.13 \\
-4.98^{* * *}\end{array}$ \\
\hline
\end{tabular}

Above we present the test statistics for both the Augmented Dickey-Fuller and the Phillips-Perron tests. The lag length was chosen using the Schwarz Information Criterion. Null Hypothesis: variable has a unit root. Note:

${ }^{* * *}$ Indicate rejection of the null hypothesis at $1 \%$ level.

${ }^{* *}$ Indicate rejection of the null hypothesis at $5 \%$ level.

" Indicate rejection of the null hypothesis at $10 \%$ level.

a Test was conducted using an intercept.

b Test was conducted using a trend and intercept.

${ }^{c}$ No trend nor intercept included.

Table A.3

Cointegration test Johansen cointegration test.

\begin{tabular}{|c|c|c|c|c|}
\hline Null hypothesis & Alternative hypothesis & & $5 \%$ Critical value & $1 \%$ Critical value \\
\hline$\lambda_{\text {trace }}$ tests & & $\lambda_{\text {trace }}$ value & & \\
\hline$r=0$ & $r>0$ & 93.06 & 76.07 & 84.45 \\
\hline$r \leq 1$ & $r>1$ & 58.10 & 53.12 & 60.16 \\
\hline$r \leq 2$ & $r>2$ & 32.62 & 34.91 & 41.07 \\
\hline$r \leq 3$ & $r>3$ & 15.92 & 19.96 & 24.60 \\
\hline$r \leq 4$ & $r>4$ & 5.15 & 9.24 & 12.97 \\
\hline$\lambda_{\max }$ tests & & $\lambda_{\max }$ value & & \\
\hline$r=1$ & $r=2$ & 25.47 & 28.14 & 33.24 \\
\hline$r=2$ & $r=3$ & 16.70 & 22.00 & 26.81 \\
\hline$r=3$ & $r=4$ & 10.77 & 15.67 & 20.20 \\
\hline$r=4$ & $r=5$ & 5.15 & 9.24 & 12.97 \\
\hline
\end{tabular}

Given the small size of our series we used a maximum of two lags running the tests. No deterministic trend.

Table A.4

Estimated matrix of adjustment coefficients.

\begin{tabular}{lllll}
\hline$\Delta C$ & $\Delta Y$ & $\Delta T A X$ & $\Delta R$ & $\Delta R E M$ \\
\hline-0.99 & -0.23 & 0.06 & 1.19 & -0.44 \\
$(0.17)$ & $(0.09)$ & $(0.34)$ & $(1.36)$ & $(0.75)$
\end{tabular}

Standard errors in parentheses.

Table A.5

INEGI survey.

\begin{tabular}{lll}
\hline & Year & Informal sector \\
\hline 2000 & 26.96 \\
2001 & 27.52 \\
2002 & 28.24 \\
2003 & 28.81 \\
2004 & 28.76 \\
2005 & 28.13 \\
2006 & 27.20 \\
\hline
\end{tabular}

Source: INEGI, Mexico.

Note: Annual averages

\section{References}

Ahumada, H., Alvarado, F., Canavese, A., 2006. The demand for currency approach and the size of the shadow economy: A critical assessment. In: Berkeley Program in Law \& Economics, Working Paper Series, Paper n. 192. University of California, Berkeley.

Bovi, M., 1999. Un miglioramento del metodo di Tanzi per la stima dell'economia sommersa in Italia, ISTAT, Rivista di Statistica Ufficiale, n. 2.

Bovi, M., Castellucci, L., 2001. Cosa sappiamo dell'economia sommersa in Italia al di là dei luoghi comuni? Alcune proposizioni empiricamente fondate. Economia Pubblica Anno XXXI (6), 77-119. 
Bovi, M., Dell'Anno, R., 2007. The changing nature of the OECD shadow economy, ISAE Working Papers 81, ISAE-Institute for Studies and Economic Analyses - Rome, Italy.

Bulîr, A., Swiston, A., 2006. What Explains Private Saving in Mexico? IMF Working Paper, n. 06/191, International Monetary Fund, Washington DC.

Cagan, P., 1958. The demand for currency relative to money supply. Journal of Political Economy 66, 302-328.

Chaudhuri, K., Chattopadhyay, S., Schneider, F., 2006. The size and development of the shadow economy: An empirical investigation from states of India. Journal of Development Economics 80 (2), 428-443.

Chiarini, B., Marzano, E., (2004). Dimensione e Dinamica dell'Economia Sommersa: Un approfondimento del Currency Demand Approach. Working Paper n. 4.2004, Università degli Studi di Napoli Parthenope", Istituto di Studi Economici, Italy.

De Soto, H., 1989. The Other Path. Harper and Row, New York.

Feige, E., 1979. How big is the irregular economy? Challenge 22, 5-13.

Frey, B., Weck-Hanneman, H., 1984. The hidden economy as an unobservable variable. European Economic Review 26 (1), 33-53.

Giles, D., Tedds, L., 2002. Taxes and the Canadian underground economy, Canadian Tax Foundation Toronto, Paper n. 106, Canada.

Guissarri, A., 1987. La Demanda de Circulante y la Informalidad en Argentina. Cuadernos de Economia 72, 197-224.

Gutmann, P., 1977. Subterranean economy. Financial Analysis Journal 33, 26-27.

Helberger, C., Knepel, H., 1988. How big is the shadow economy? A re-analysis of the Unobserved variable approach of B. S. Frey and H. Weck- Hannemann. European Economic Journal 32, 965-976.

Hendry, D., 1995. Dynamic Econometrics. Oxford University Press, Oxford, UK.

Hernandez-Coss, R., 2005. The US-Mexico Remittance Corridor. Lessons on Shifting from informal to formal transfer systems, Working Paper n. 47, The World Bank, Washington, DC.

IMF Country Report. 2005. Mexico: Selected Issues, Report 05/428, International Monetary Fund, Washington DC.

Kaufmann, D., Kaliberda, A., 1996. Integrating the unofficial economy into the dynamics of the post-socialist economies: A framework of analysis and evidence. In: Kaminski, B. (Ed.), Economic Transition in Russia and the New States of Eurasia. M.E. Sharpe, Inc., Armont, New York.

Klovland, J., 1984. Tax evasion and demand for currency in Norway and Sweden. Is there a hidden relationship? Scandinavian Journal of Economics 86, 423-439.

Loayza, N., 1997. The economics of the informal sector: A simple model and some empirical evidence from Latin America, World Bank Policy Research Working Paper, WPS 1727, The World Bank, Washington, DC.

OECD, 2007. Policy Coherence for Development-Migration and developing Countries. The Development Centre, Paris, France.

Öğ́̈inç, F., Yilmaz, G., 2000. Estimating the underground economy in Turkey, Discussion Paper, The Central Bank of the Republic of Turkey, Turkey.

Portes, A., Castells, M., Benton, L., 1989. World underneath: The origins, dynamics, and effects of the informal economy. In: Portes, A., Castells, M., Benton, L. (Eds.), The Informal Economy: Studies in Advanced and Less Developed Countries. Johns Hopkins University Press, Baltimore.

Portes, A., Haller, W., 2005. The informal economy. In: Smelser, N., Swedberg, R. (Eds.), Handbook of Economic Sociology, 2nd ed. Russell Sage Foundation.

Roubaud, F., 1995. La Economia Informal en Mexico. De la esfera domestica a la dinamica macroeconomica, Fondo de Cultura Economica, Mexico.

Schneider, F., Enste, D., 2000. Shadow economies: size, causes and consequences. Journal of Economic Literature, American Economic Association 38, 77-114.

Schneider, F., 2002. Size and measurement of the informal economy in 110 countries around the world, Rapid Response Unit, The World Bank, Washington, DC.

Shima, I., 2004. The shadow economy in Norway: Demand for currency approach, Memorandum n. 10/2004, Frisch Center of Economic Research \& Department of Economics, University of Oslo, Norway.

Spiro, P., 1996. Monetary estimates of the underground economy: A critical evaluation. The Canadian Journal of Economics/Revue Canadienne d'Economique 29, S171-S175.

Tanzi, V., 1983. The underground economy in the United States: Annual estimates, 1930-1980, IMF Staff Papers, 33, International Monetary Fund, pp. 283-305.

Tedds, L., 1998. Measuring the size of the hidden Economy in Canada, MA extended essay. University of Victoria, Department of Economics, Canada.

The International Bank for Reconstruction and Development/The World Bank. 2007. Close to Home. The Development Impact of Remittances in Latin America, Washington, DC.

Vuletin, G., 2008. Measuring the Informal Economy in Latin America and the Caribbean. IMF Working Paper, WP/08/102, International Monetary Fund, Washington DC

World Bank. 2006. Global Economic Prospects 2006-Economic Implications of Remittances and Migration, The World Bank, Washington, DC. 